\title{
Study of Nd Deposition onto W and Mo Cathodes from Molten Oxide-Fluoride Electrolyte
}

\author{
Vesna S. Cvetkovićc ${ }^{*}$, Nataša M. Vukićevićl, Dominic Feldhaus ${ }^{2}$, Tanja S. Barudžija ${ }^{3}$, \\ Jasmina S. Stevanović ${ }^{1}$, Bernd Friedrich ${ }^{2}$, Jovan N. Jovićevićl ${ }^{1}$ \\ ${ }^{1}$ Department of Electrochemistry, Institute of Chemistry, Technology and Metallurgy, National \\ Institute, University of Belgrade, Njegoševa 12, 110000 Belgrade, Serbia; \\ ${ }^{2}$ IME Process Metallurgy and Metal Recycling, Institute of RWTH Aachen University, Intzestrasse 3, \\ 52056 Aachen, Germany; \\ ${ }^{3}$ Institute for Nuclear Sciences Vinča, University of Belgrade, P.O.Box 522, 11001 Belgrade, Serbia \\ *E-mail: v.cvetkovic@ihtm.bg.ac.rs;
}

Received: 8 April 2020 / Accepted: 19 May 2020 / Published: 10 June 2020

Electrochemical reduction processes of $\mathrm{Nd}(\mathrm{III})$ on tungsten and molybdenum electrodes in $\mathrm{NdF}_{3}+\mathrm{LiF}$ and $\mathrm{NdF}_{3}+\mathrm{LiF}+\mathrm{Nd}_{2} \mathrm{O}_{3}$ were investigated by cyclic voltammetry, chronoamperometry and open circuit measurements. Electrolytes and electrodes were examined after neodymium electrodeposition by optical microscopy and XRD. It was found that tungsten and molybdenum working electrodes behave identically during neodymium complexed ion reduction processes. Their reversible potentials in the electrolytes used differed only by $10 \mathrm{mV}$, and so did the potentials of the neodymium ion reduction processes. The recorded results indicated that the $\mathrm{Nd}(\mathrm{III})$ ions in the melts were reduced in two steps: $\mathrm{Nd}(\mathrm{III}) \rightarrow \mathrm{Nd}(\mathrm{II})$ and $\mathrm{Nd}(\mathrm{II}) \rightarrow \mathrm{Nd}(0)$. These consecutive processes are predominantly mass transfer controlled. Electrolytically obtained metal appeared to accumulate on the cathode and no metal neodymium was recorded in the solidified electrolyte placed close to the cathode after completed electrodeposition process. However, it was found that $\mathrm{NdF}_{2}$ formed by the disproportionation reaction between $\mathrm{Nd}(\mathrm{III})$ and that deposited $\mathrm{Nd}(0)$ coexists with other complex components in the electrolytes used.

Keywords: Neodymium electrodeposition, Molybdenum, Tungsten, Oxide-fluoride molten salt electrolyte

\section{INTRODUCTION}

Rare earth (RE) elements, in their conductive and magnetic materials, fulfil important functions in diverse industrial applications, including the fields of green and high technology [1-3]. Because of the constant increase in applications where RE metals, especially Pr, Nd, Dy, are needed, their use will 
increase steadily in the future [1,3-5]. In order to provide a long term sustainable supply of rare earth elements, especially in industrialized countries without own RE basis, recycling and recovery of these elements from waste or from ores became significantly important. Based on the form of the starting materials (scrap or sludge), different processes, from pyrometallurgical, hydrometallurgical to electrochemical, are used respectively combined for the production of pure rare earth metals [6]. One of interesting process steps which include industrial production of neodymium metal, is molten salt electrolysis, which is considered as an adequate alternative to metallothermic reduction [7].

Although the interest in the neodymium electrodeposition mechanism from melts is increasing, there is still only a small number of accessible published works devoted to $\mathrm{Nd}$ electrodeposition onto molybdenum [1,3,8-12] and tungsten [4,13-15] as working electrodes, from fluoride [1,8-10,13-15] and chloride $[3,4,11,12]$ melts.

In order to perform the process of neodymium electrodeposition successfully, it is important to select a suitable combination of neodymium salts and solvents in order to compose a suitable electrolyte [14,16-18]. High temperature molten salt mixtures, based on chlorides or fluorides, are used as appropriate electrolytes for neodymium electrodeposition. Comparing to chloride molten salts, fluoride electrolytes exhibit higher conductivity and lower hygroscopicity. It is also possible to achieve higher current efficiency of the neodymium electrodeposition process in fluoride electrolytes $[10,13,19]$.

Attaining a viable yield of electrochemically deposited $\mathrm{Nd}$ is a challenge from the practical application standpoint. In order to study this further, a number of studies have been devoted to the reduction mechanism of neodymium ions in different electrolytes: fluoride molten salts, alkali and alkaline earth chloride electrolytes, or mixed fluoride chloride melts. However, no agreement on the mechanism of neodymium (III) reduction has been reached as of yet. Investigations done by Huang et al. [13] in $\mathrm{NdF}_{3}+\mathrm{LiF}, \mathrm{NdF}_{3}+\mathrm{LiF}+\mathrm{Nd}_{2} \mathrm{O}_{3}+\mathrm{Nd}$ (excess) and Liu et al. [14] in $\mathrm{NdF}_{3}+\mathrm{LiF}, \mathrm{NdF}_{3}+\mathrm{LiF}+\mathrm{Nd}$, $\mathrm{NdF}_{3}+\mathrm{LiF}+\mathrm{Nd}_{2} \mathrm{O}_{3}$ on $\mathrm{W}$ working electrode, and by Shiguan et al. [9] in $\mathrm{NdF}_{3}+\mathrm{LiF}+\mathrm{CaF}_{2}$, $\mathrm{NdF}_{3}+\mathrm{LiF}+\mathrm{CaF}_{2}+\mathrm{Nd}_{2} \mathrm{O}_{3}$ molten salts on Mo cathode have prompted authors to conclude that $\mathrm{Nd}$ (III) ions in the fluoride melts are electrochemically reduced to $\mathrm{Nd}(0)$ in two consecutive steps. However, the works conducted by Stefanidaki et al. [15] in $\mathrm{NdF}_{3}+\mathrm{LiF}+\mathrm{Nd}_{2} \mathrm{O}_{3}$, Hamel et al. [8] in $\mathrm{NdF}_{3}+\mathrm{LiF}+\mathrm{CaF}_{2}$, Thudum et al. [10] in $\mathrm{NdF}_{3}+\mathrm{LiF}+\mathrm{CaF}_{2}+\mathrm{Nd}_{2} \mathrm{O}_{3}$ on $\mathrm{W}$ cathodes and Abbalisadeh et al. [1] in $\mathrm{NdF}_{3}+\mathrm{LiF} / \mathrm{FeF}_{3} / \mathrm{Nd}_{2} \mathrm{O}_{3}$ electrolytes on Mo working electrode, claim that $\mathrm{Nd}$ (III) ions are reduced to $\mathrm{Nd}(0)$ in fluoride melts in a single step process via three exchanged electrons.

Data found in the literature regarding the neodymium (III) reduction process in chloride melts likewise demonstrated discrepancies between the results. In a study done in molten $\mathrm{LiCl}+\mathrm{KCl}+\mathrm{NdCl}_{3}$ and $\mathrm{LiCl}+\mathrm{KCl}+\mathrm{CsCl}+\mathrm{NdCl}_{3}$ electrolytes on the $\mathrm{Mo}$ electrode by Novoselova et al. [11] authors concluded that the reduction of $\mathrm{Nd}(\mathrm{III})$ ions to $\mathrm{Nd}(0)$ is a two step mechanism. Similar conclusions, in terms of the electrochemical behaviour of $\mathrm{Nd}(\mathrm{III})$ ions from $\mathrm{NdCl}_{3}$ in the eutectic $\mathrm{LiCl}+\mathrm{KCl}$ molten salts were obtained by Tang et al. [12] on Mo cathode, and Shen et al. [4] on W working electrode. Meanwhile, Hua et al. [3] claimed that the $\mathrm{Nd}(\mathrm{III})$ ions in the eutectic $\mathrm{NaCl}-\mathrm{KCl}$ melts containing $\mathrm{NdCl}_{3}$ can be directly reduced to $\mathrm{Nd}$ metal on molybdenum electrode through a single step mechanism.

This study pursued the understanding of the reaction mechanism of $\mathrm{Nd}$ deposition and better control of the electrolysis process in the quest for high yield of metallic neodymium. The approach was to choose the substrate that would neither form an alloy with neodymium during electrochemical 
deposition nor react with the electrolyte. The elements which could meet these requirements are molybdenum and tungsten, so both metals were used as inert cathodes in this investigation.

\section{EXPERIMENTAL}

A graphite crucible containing the electrolyte was introduced into the stainless-steel cell closed by a water-cooled stainless-steel lid with Swagelok connections. The experimental apparatus was placed into a resistance heated furnace. All experiments were performed under an argon atmosphere while the cooled lid provided the insertions points of the electrodes into the cell while trapping the harmful gases formed during the experiments. Using a programmable furnace, the cell was heated and the temperature was measured by a Type B thermocouple that was connected via Swagelok connectors. All experiments were performed at $1050 \pm 1{ }^{\circ} \mathrm{C}$.

Following inert working electrodes were used in the electrochemical experiments: Molybdenum wire (Mo, 2 mm diameter, EWG 99.95\%), Tungsten wire (W, $1 \mathrm{~mm}$ diameter, EWG 99.9\%). The counter electrode was a $4 \mathrm{~mm}$ diameter glassy carbon $\operatorname{rod}(>99.99 \%$ HTW SIGRADUR® G). All the potentials of the working electrodes (Mo or W) in this work were referenced to the tungsten reference electrode ( $2 \mathrm{~mm}$ diameter rod). Before the experiments were conducted, the surface of the electrodes was polished thoroughly by $\mathrm{SiC}$ emery paper then consecutively rinsed with deionized water and ethanol then dried. After the electrolyte was melted, the electrodes were immersed into the cell.

The electrolytes used in the experiments were: $\mathrm{NdF}_{3}+\mathrm{LiF}: 87.5$ wt.\% neodymium fluoride (Treibacher, $\geq 99.9 \%$ ) +12.5 wt.\% lithium fluoride (STREM Chemicals, Inc., 99.9\%); $\mathrm{NdF}_{3}+\mathrm{LiF}+\mathrm{Nd}_{2} \mathrm{O}_{3}: 87.5$ wt. $\%$ neodymium fluoride +12.5 wt. $\%$ lithium fluoride +2 wt. $\%$ of $\mathrm{Nd}_{2} \mathrm{O}_{3}$ (Treibacher, 99.8\%). This neodymium fluoride composition was selected because it showed to be the most suitable in terms of the melting temperature and the viscosity of the electrolyte $[16,20]$.

Preparation of the electrolytes was done according to the following steps: first, $\mathrm{NdF}_{3}$ and $\mathrm{LiF}$ were dried separately at $250{ }^{\circ} \mathrm{C}$ for $24 \mathrm{~h}$. Then the chemicals were mixed, placed in a graphite crucible, melted and homogenised at $1050{ }^{\circ} \mathrm{C}$ under argon gas atmosphere of 1800 mbar in a vacuum induction furnace. Finally, when the reactor was cooled down to room temperature, the prepared solid electrolyte was taken out and stored in a glovebox under high purity argon atmosphere, with $\mathrm{H}_{2} \mathrm{O}$ and $\mathrm{O}_{2}$ levels below 1 ppm. $\mathrm{Nd}_{2} \mathrm{O}_{3}$, was dried for 24 hours at $120^{\circ} \mathrm{C}$. The resulting dried powder was pressed, crushed and sieved to a particle size between $0.70-2.0 \mathrm{~mm}$.

An IviumStat potentiostat (5 A and $10 \mathrm{~V}$; Ivium Technologies) was used to perform all electrochemical experiments. Cyclic voltammetry (CV), chronoamperometry and open-circuit chronopotentiometry were employed for the investigation of the $\mathrm{Nd}$ (III) ions reduction processes from the electrolytes used. On both cathodes, CV experiments were carried out starting from the initial potential, slighly more negative than the open circuit potential of the corresponding working electrode $(50-100 \mathrm{mV})$, to a different cathodic end potential, then back to the starting potential, with various scan rates $\left(50-800 \mathrm{mVs}^{-1}\right)$. In order to further examine the reduction/oxidation mechanism of $\mathrm{Nd}$ ions in the used oxide-fluoride electrolyte on the tungsten cathode, voltammograms were recorded within the same potential range with the scan interrupted at the cathodic end potential $(-1.00 \mathrm{~V})$ and the potential held 
for 5, 60, and $180 \mathrm{~s}$ before starting the return scan. The second set of experiments included applying cathodic deposition potential of $-0.90 \mathrm{~V}$ for 5 and $10 \mathrm{~s}$ onto the molybdenum and tungsten working electrodes, whereupon the applied potential was switched off and the open-circuit potential of the electrode was registered as a function of time.

Neodymium electrodeposition was conducted on molybdenum or tungsten cathode at different constant overpotentials in the $\mathrm{NdF}_{3}+\mathrm{LiF}+\mathrm{Nd}_{2} \mathrm{O}_{3}$ electrolyte system at $1050{ }^{\circ} \mathrm{C}$. After the deposition, working electrode was taken out from the molten electrolyte but kept inside the cell. When the system was completely cooled down the electrode was withdrawn from the cell and kept under vacuum.

The surfaces of the samples - deposits were examined by optical microscope (Keyence; model VH-Z100R, Japan). The cathodes-deposits and electrolyte samples placed close to the electrode were analysed by X-ray diffraction (XRD) with Philips PW 1050 powder diffractometer at room temperature with Ni filtered $\mathrm{CuK} \alpha$ radiation $\left(\lambda=1.54178 \AA\right.$ ), scintillation detector within $20-85^{\circ} 2 \theta$ range in steps of $0.05^{\circ}$, and scanning time of $5 \mathrm{~s}$ per step.

\section{RESULTS AND DISCUSSION}

Typical voltammograms obtained on tungsten and molybdenum cathode from $\mathrm{LiF}+\mathrm{NdF}_{3}$ and from $\mathrm{LiF}+\mathrm{NdF}_{3}+\mathrm{Nd}_{2} \mathrm{O}_{3}$ melts are presented in Figs. 1a) and b), respectively. Under the same conditions applied to the system, the current densities recorded for the same potential applied were several times higher in $\mathrm{LiF}+\mathrm{NdF}_{3}+\mathrm{Nd}_{2} \mathrm{O}_{3}$ melt than in $\mathrm{LiF}+\mathrm{NdF}_{3}$. Otherwise, the general appearance of the voltammograms reflecting cathodic and anodic processes within the same potential range applied were very similar indeed. The reason for the recorded difference in current densities is not obvious. There is little published research on the subject of the neodymium fluoride electrolytes structures and complex ions therein [21]. Some authors claim that $\mathrm{Nd}-\mathrm{F}$ complex ions found in the $\mathrm{NdF}_{3}+\mathrm{LiF}$ mixture are dominantly $\left[\mathrm{NdF}_{4}\right]^{-}[21]$, others consider $\left[\mathrm{NdF}_{6}\right]^{3-}$ as the main form [15], but generally accepted viewpoint is that $\left[\mathrm{NdF}_{6}\right]^{3-},\left[\mathrm{NdF}_{4}\right]^{-}$and $\mathrm{F}^{-}$coexist in $\mathrm{NdF}_{3}+\mathrm{LiF}$ melts $[10,21]$. When added to the fluoride melts (made of $\mathrm{LiF}, \mathrm{CaF}_{2}, \mathrm{NdF}_{3}$ ), $\mathrm{Nd}_{2} \mathrm{O}_{3}$ dissolves under diffusion control and forms oxyfluorides $\mathrm{NdOF}$ or $\left[\mathrm{NdOF}_{5}\right]^{4-}[1,7,10,21,22]$. Which of the complex species in the electrolyte $\left(\left[\mathrm{NdF}_{4}\right]^{-},\left[\mathrm{NdF}_{6}\right]^{3-}\right.$, $\left[\mathrm{NdOF}_{5}\right]^{4-}$ ), will be predominantly involved and with what reaction rate in the reactions recorded in the voltammograms, depends on the molar ratio of neodymium oxyfluoride ions/neodymium fluoride ions $[10,15]$, current density and electrode potential applied [23,24].

In the voltammograms from both working electrodes, $\mathrm{W}$ and Mo, there are two characteristic cathodic current peaks $\left(\mathrm{C}_{1}\right.$ and $\left.\mathrm{C}_{2}\right)$ and their two corresponding anodic peaks $\left(\mathrm{A}_{1}\right.$ and $\left.\mathrm{A}_{2}\right)$, Figs. 1a) and b). Voltammograms obtained, on both substrates, by cathodic end potential advancing towards more negative values are presented in Figs. 2a) and b). Only when a potential negative to the cathodic peak potential $\mathrm{C}_{1}$ or $\mathrm{C}_{2}$ was applied, could the corresponding anodic peaks $\mathrm{A}_{1}$ and $\mathrm{A}_{2}$ be recorded. The peak potentials observed in the voltammograms obtained on $\mathrm{W}$ and Mo electrodes under all other conditions of experiment kept the same, were very close in value. 

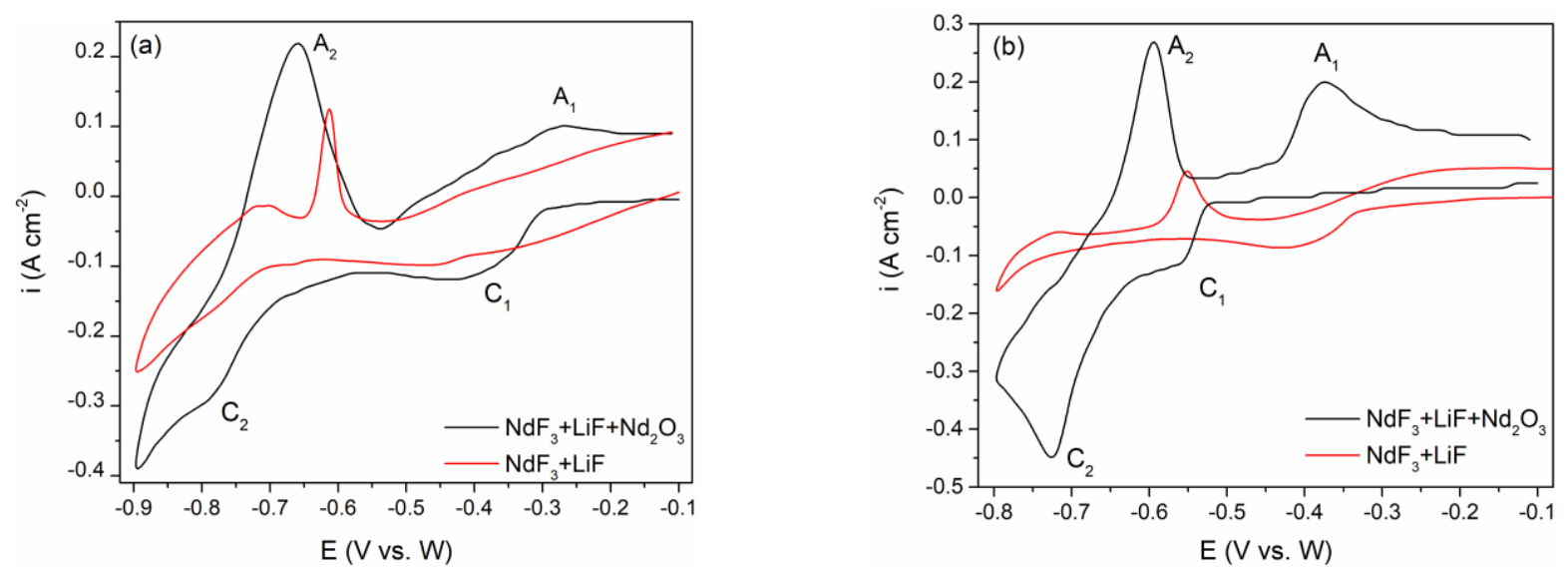

Figure 1. Cyclic voltammograms recorded in two different electrolytes used, scan rate $100 \mathrm{mVs}^{-1}, \mathrm{~T}=$ $1050^{\circ} \mathrm{C}$; a) on $\mathrm{W}$ electrode; b) on Mo electrode.

On the tungsten electrode, $\mathrm{C}_{1}$ peak is at $\approx-0.40 \mathrm{~V}$ vs. $\mathrm{W}, \mathrm{A}_{1}$ peak at $\approx-0.30 \mathrm{~V}$ vs. $\mathrm{W}, \mathrm{C}_{2}$ peak at $\approx-0.74 \mathrm{~V}$ vs. $\mathrm{W}$, and $\mathrm{A}_{2}$ peak at $\approx-0.65 \mathrm{~V}$ vs. W. On the molybdenum electrode, $\mathrm{C}_{1}$ peak is at $\approx-$ $0.50 \mathrm{~V}$ vs. $\mathrm{W}, \mathrm{A}_{1}$ peak at $\approx-0.35 \mathrm{~V}$ vs. $\mathrm{W}, \mathrm{C}_{2}$ peak at $\approx-0.75 \mathrm{~V}$ vs. $\mathrm{W}$, and $\mathrm{A}_{2}$ peak at $\approx-0.57 \mathrm{~V}$ vs. $\mathrm{W}$. However, on the $\mathrm{W}$ electrodes, the reduction current peak potentials and oxidation current peak potentials were more positive than on the Mo electrodes. The current densities recorded as a response to the electrochemical investigation method applied were very similar in value as well.

The results presented in Figures 1 and 2, indicated that there were two reversible processes taking place. Peaks $\mathrm{C}_{1}$ and $\mathrm{A}_{1}$ should reflect redox process $\mathrm{Nd}(\mathrm{III})+\mathrm{e}^{-} \leftrightarrow \mathrm{Nd}(\mathrm{II})$ and peaks $\mathrm{C}_{2}$ and $\mathrm{A}_{2}$ redox process $\mathrm{Nd}(\mathrm{II})+2 \mathrm{e}^{-} \leftrightarrow \mathrm{Nd}(0)$ on both substrates $[9,13,14,20]$. Therefore, it can be assumed that deposition and dissolution of neodymium from the fluoride melts used on the substrates chosen (W and Mo) proceed in two steps. It should be mentioned that some authors describe the electrochemical reduction of neodymium ions from neodymium fluorides or neodymium oxyfluoride electrolytes on inert electrodes as a one step process $[1,8,10,15,25-27]$ and others as a twostep process $[9,13,14,20]$.
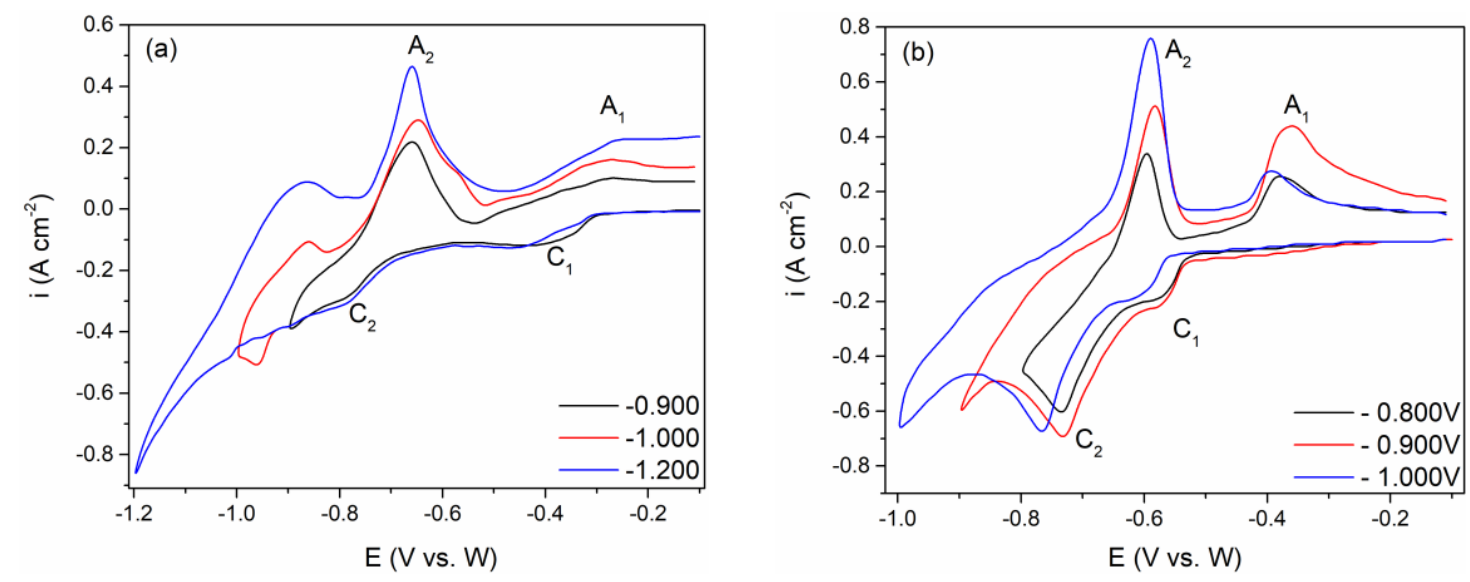

Figure 2. Cyclic voltammograms recorded in $\mathrm{NdF}_{3}+\mathrm{LiF}+\mathrm{Nd}_{2} \mathrm{O}_{3}$ electrolyte, at $1050{ }^{\circ} \mathrm{C}$; a) on $\mathrm{W}$ working electrode, scan rate $100 \mathrm{mVs}^{-1}$; b) on Mo working electrode, scan rate $200 \mathrm{mVs}^{-1}$. 
Further study of the two processes included the data obtained in the voltammograms from Figs. 3 and 4. Cyclic voltammograms obtained with different scan rates, on both cathodes $\mathrm{W}$ and Mo, within the potential range from $-0.10 \mathrm{~V}$ to $-0.80 \mathrm{~V}$ or $-0.90 \mathrm{~V}$ vs. $\mathrm{W}$ respectively, Figs. 3a) and $4 \mathrm{a}$ ) showed that maximum current densities of the cathodic $\left(\mathrm{C}_{1}\right)$ and anodic peak $\left(\mathrm{A}_{1}\right)$ increased, but their peak potential differential was relatively small. Similar observation were made for cathodic $\left(\mathrm{C}_{2}\right)$ and its corresponding anodic response $\left(A_{2}\right)$ on both cathodes. These findings imply reversibility of the redox processes [13]. The plots derived from Figs. $3 a)$ and $4 a)$ using cathodic $\left(C_{1}\right)$ and corresponding anodic peak $\left(A_{1}\right)$ current densities versus the square root of the scan rates applied, according to the analysis proposed elsewhere [28], appeared to be linear but did not pass through the origin, Figs. 3b) and 4b). This should suggest that the redox process $\mathrm{Nd}$ (III) $\leftrightarrow \mathrm{Nd}$ (II) is under mixed control, both by the mass transfer of the complexed $\mathrm{Nd}$ ions and the rate of their charge transfer step which includes complicated disbanding and formation of the complexes [13,20]. Furthermore, the plots obtained from Figs. 3c) and 4c) presenting the peak currents for the peak $\left(\mathrm{C}_{2}\right)$ as a function of the square root of the scan rates applied, proved to be linear and also did not pass through the origin. This indicates that $\mathrm{Nd}(\mathrm{II}) \leftrightarrow \mathrm{Nd}(0)$ the redox process, on the inert cathodes used, was controlled by mass transfer of complexed $\mathrm{Nd}$ (II) and that the charge transfer step rate was complicated most probably by the disassembling of fluoride and oxyfluoride complexes involved $[9,13,14,20]$.
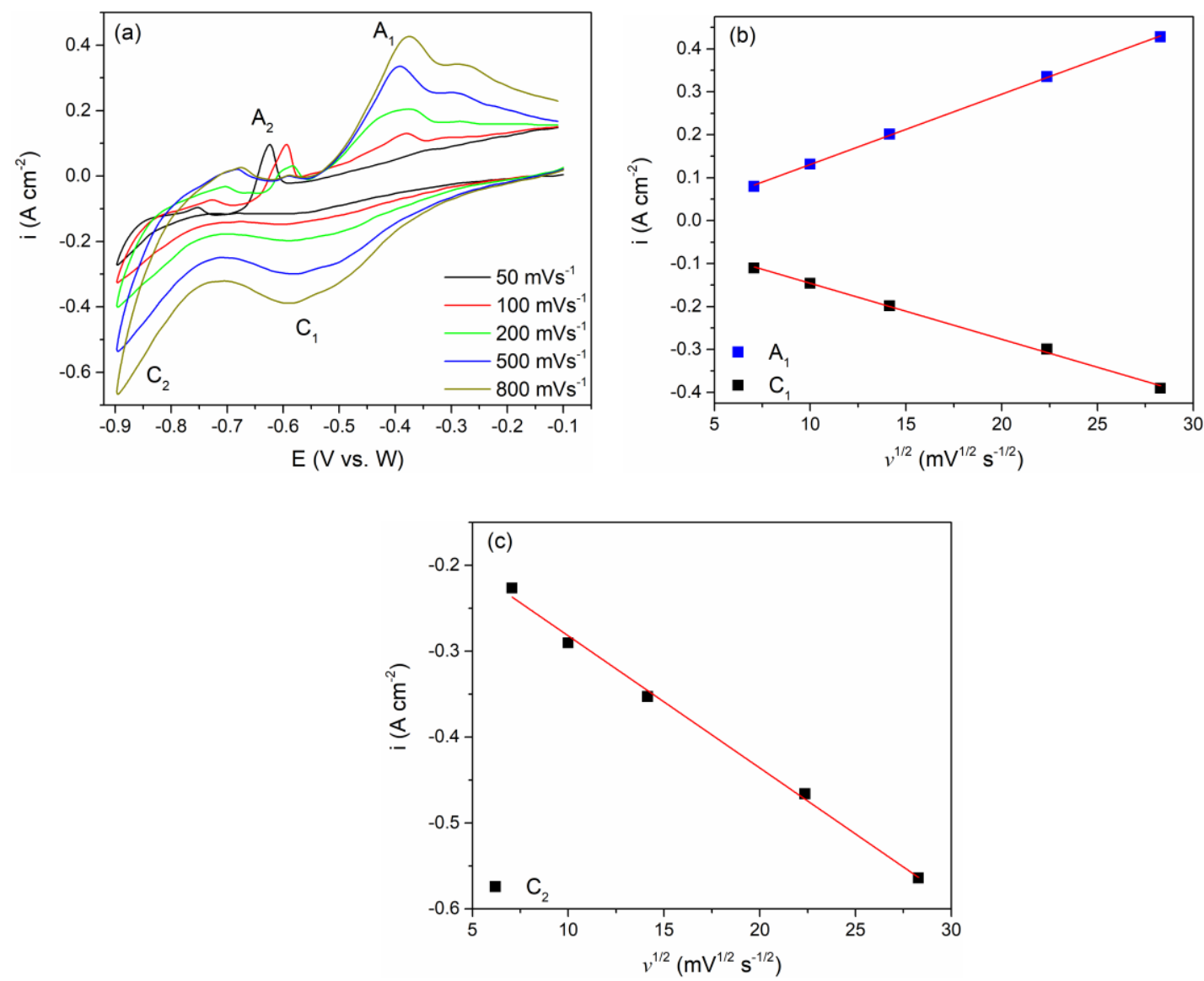

Figure 3. a) Cyclic voltammograms obtained on $\mathrm{W}$ cathode in $\mathrm{NdF}_{3}+\mathrm{LiF}+\mathrm{Nd}_{2} \mathrm{O}_{3}$ electrolyte, scanned with various scan rates; b) and c) relationship between cathodic and anodic peaks current density $v s$. the square root of the scan rates applied derived from Fig. 3a). 

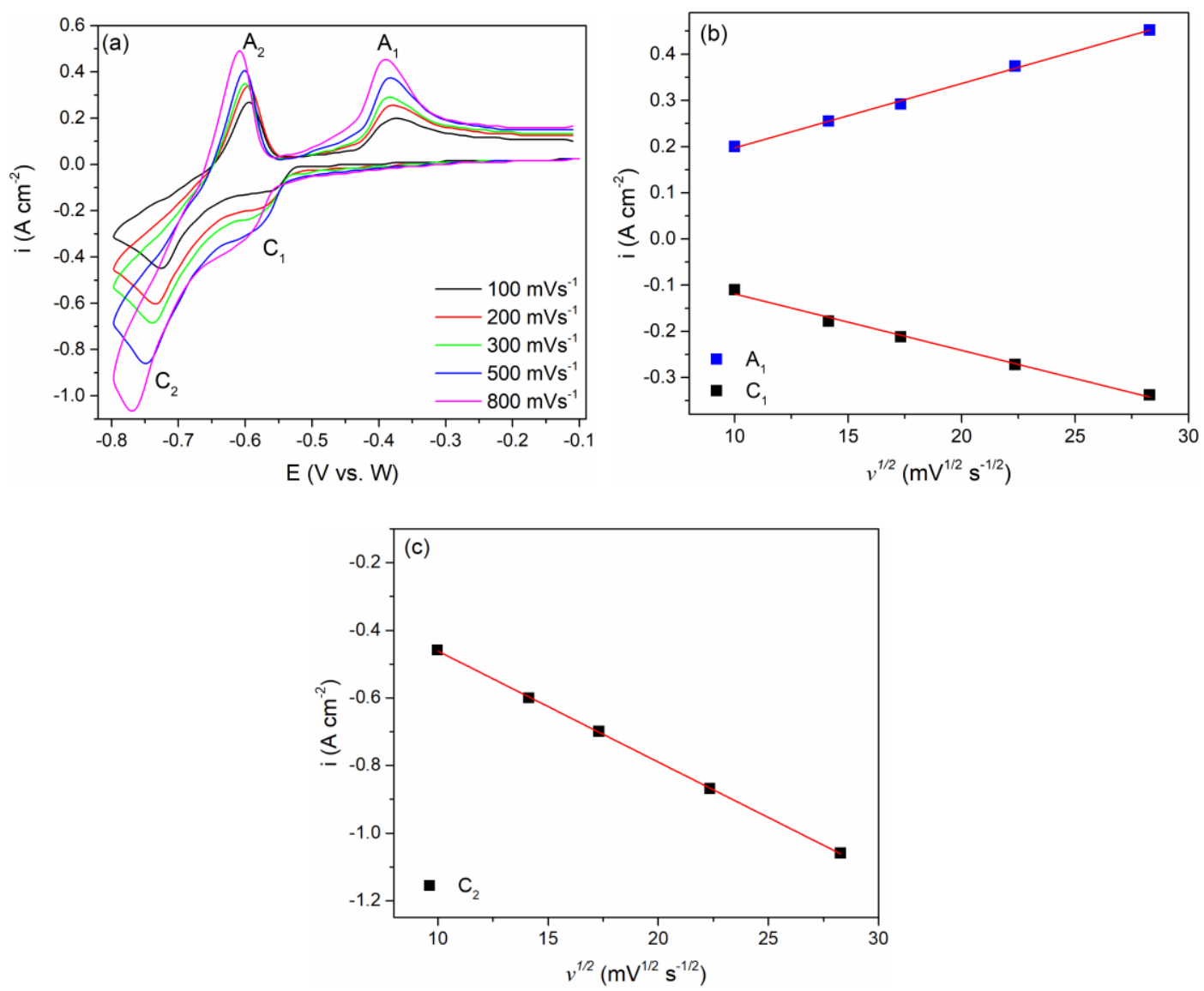

Figure 4. a) Voltammograms obtained on Mo cathode in $\mathrm{NdF}_{3}+\mathrm{LiF}+\mathrm{Nd}_{2} \mathrm{O}_{3}$ electrolyte, scanned with various scan rates; b) and c) relationship between cathodic and anodic peaks current density $v s$. the square root of the scan rates applied derived from Fig. 4a).

Electrochemical composition of the electrolyte used (in molar units $\mathrm{LiF}: \mathrm{NdF}_{3}=5: 1$ and in mass percentage $\left[\mathrm{LiF}+\mathrm{NdF}_{3}\right]: \mathrm{Nd}_{2} \mathrm{O}_{3}=98 \%: 2 \%$ ) depends mainly on $\mathrm{NdF}_{3}$ and $\mathrm{Nd}_{2} \mathrm{O}_{3}$ dissolution in the $\mathrm{LiF}$ solvent. The dissolution of $\mathrm{Nd}_{2} \mathrm{O}_{3}$ in $\mathrm{LiF}$ and $\mathrm{NdF}_{3}$ leads to the formation of $\left[\mathrm{NdF}_{6}\right]^{3-}$ and $\left[\mathrm{NdOF}_{5}\right]^{4-}$ complex ions and it is particularly limited and controlled by diffusion. With the excess of the LiF and $\mathrm{NdF}_{3}$, ions $\left[\mathrm{NdF}_{6}\right]^{3-}$ and $\left[\mathrm{NdOF}_{5}\right]^{4-}$ are expected to co-exist in the melt with oxide $[10,15]$. Both of the ions are the source for $\mathrm{Nd}$ metal after being reduced [10,15]:

$$
\begin{aligned}
& {\left[\mathrm{NdF}_{6}\right]^{3-}+3 \mathrm{e}^{-} \leftrightarrow \mathrm{Nd}^{2+}+6 \mathrm{~F}^{-} \text {and } \mathrm{Nd}^{2+}+2 \mathrm{e}^{-} \leftrightarrow \mathrm{Nd},} \\
& {\left[\mathrm{NdOF}_{5}\right]^{4-}+\mathrm{e}^{-} \leftrightarrow \mathrm{NdF}_{2}+\mathrm{O}^{2-}+3 \mathrm{~F}^{-} \text {and } \mathrm{NdF}_{2}+2 \mathrm{e}^{-} \leftrightarrow \mathrm{Nd}+2 \mathrm{~F}^{-} .}
\end{aligned}
$$

During the electrolytic production of neodymium from oxide-fluoride melts on the cathode, oxidation of neodymium oxyfluorides might generate oxygen at the anode according to the following equations [27]:

$$
3\left[\mathrm{NdOF}_{5}\right]^{4-}-6 \mathrm{e}^{-}=3 / 2 \mathrm{O}_{2}(\mathrm{~g})+3 \mathrm{Nd}^{3+}+15 \mathrm{~F}^{-} .
$$

The generated oxygen species subsequently could react with the carbon anode and $\mathrm{CO}$ and $\mathrm{CO}_{2}$ gases are produced. However, with $\mathrm{F}^{-}$being present $\mathrm{CF}_{4}$ and $\mathrm{C}_{2} \mathrm{~F}_{6}$ gases can be also evolved [16]. Higher neodymium deposition overpotential will provoke more positive anodic potential, and probably more ecologically dangerous gasses will be evolved. 
Figure 5 shows the voltammograms when the cathodic end potential of the $\mathrm{W}$ working substrate was held at $-1.00 \mathrm{~V}$ vs. $\mathrm{W}$, for varying intervals before it was returned to positive values. Increased holding time at the cathodic end-potential, which was equivalent to at least - $0.25 \mathrm{~V}$ of the overpotential to the $\mathrm{C}_{2}$ peak potential in previously recorded voltammograms, on tungsten electrode induced visible increase of the surface limited by anodic peak $\mathrm{A}_{2}$ of the voltammogram. This reflects an increase in the quantity of $\mathrm{Nd}$ metal previously deposited and now being dissolved when working potential turned to values more positive than the neodymium deposition potential. The same was recorded on molybdenum electrode under very similar working conditions [20].

These conclusions are supported by the open circuit measurements recorded after different durations of neodymium deposition. Open circuit measurements registered the start of dissolution of a solid phase at around $-0.70 \mathrm{~V}$ vs. W on both, tungsten and molybdenum electrode, Figs. 6a) and b), respectively. According to the open-circuit measurements in Fig. 6, the existence of a plateau at a potential of $\approx-0.68 \mathrm{~V}$, after deposition on Mo or $\mathrm{W}$ cathode at $\mathrm{E}_{\mathrm{dep}}=-0.90 \mathrm{~V}$ for only 5 or $10 \mathrm{~s}$, suggests dissolution of the deposited solid phase $\mathrm{Nd}$ from the surface of the inert working electrode.

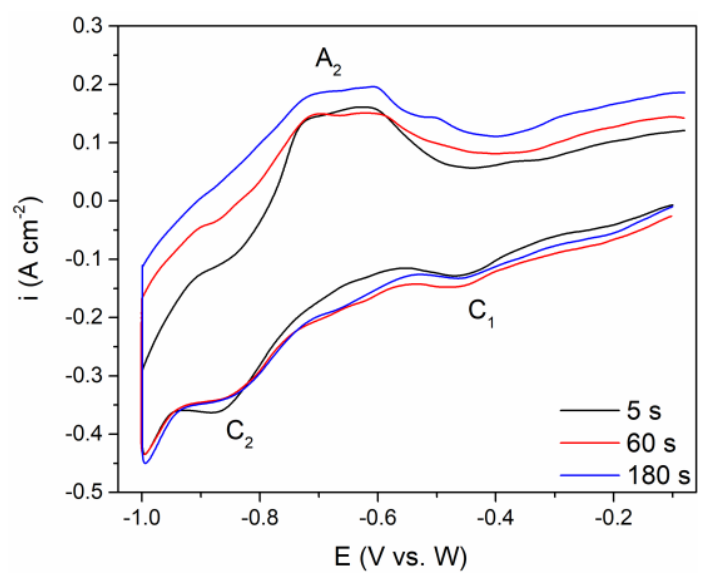

Figure 5. Voltammograms obtained on $\mathrm{W}$ electrode in molten oxide-fluoride electrolyte with different "holding times" $(\mathrm{t}=5,60$ and $180 \mathrm{~s})$ at the cathodic end potential of the cycle $\mathrm{E}_{\mathrm{F}}=-1.00 \mathrm{~V}$ vs. $\mathrm{W}$, scan rate $=100 \mathrm{mVs}^{-1}$.

These values are in good agreement with the values offered by $\mathrm{A}_{2}$ peaks in the voltammograms recorded on both substrates, Figs. 1-5. The dissolution of the deposited neodymium proceeds relatively slowly, which indicates the problems characteristic to neodymium ions diffusion from the working electrode into the electrolyte bulk and formation of complex fluoride and oxyfluoride complex ions on the way. 

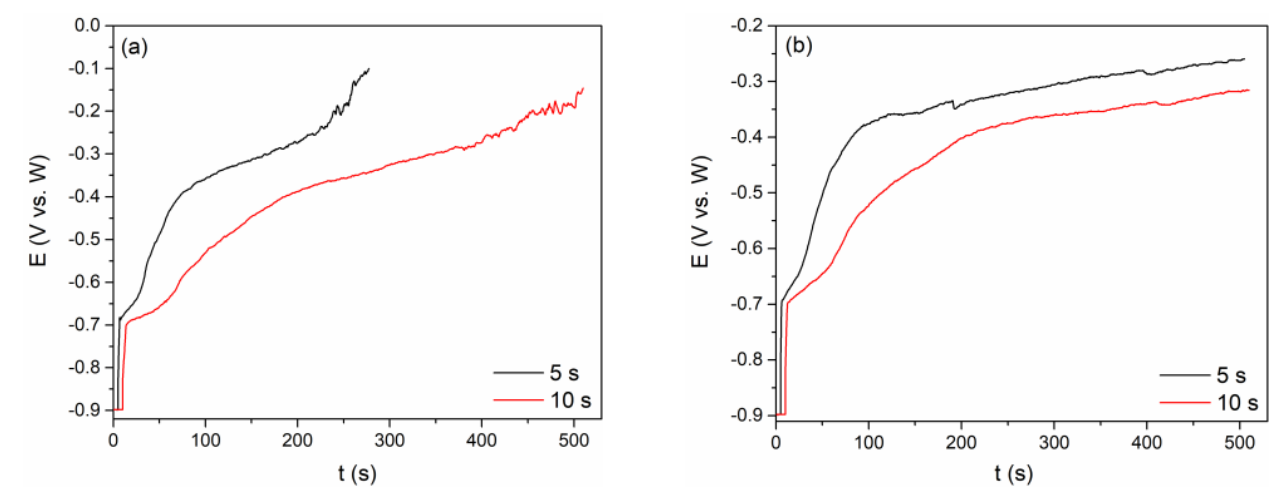

Figure 6. Open-circuit potential transient curves obtained after short polarization $(\mathrm{t}=5$ and $10 \mathrm{~s})$, at $0.90 \mathrm{~V}$ vs. $\mathrm{W}$ in molten $\mathrm{NdF}_{3}+\mathrm{LiF}+\mathrm{Nd}_{2} \mathrm{O}_{3}$ electrolyte; a) on $\mathrm{W}$ electrode b) on Mo electrode.

There is a reaction appearing almost immediately after the first $\mathrm{Nd}$ metal is deposited at the working electrode, $\mathrm{W}$ and Mo alike. It is provoked by the coexistence of $\mathrm{Nd}(\mathrm{II})$ and $\mathrm{Nd}(\mathrm{III})$ in the electrolyte in the presence of metal $\mathrm{Nd}$ [13]:

$$
2 \mathrm{Nd}(\mathrm{III})+\mathrm{Nd} \rightarrow 3 \mathrm{Nd}(\mathrm{II})
$$

and cannot be avoided. This reaction of disproportionation (comproportionation) decreases the yield of neodymium electrodeposition [14]. Figure 7 presents schematic presentation of the processes taking part on the molybdenum/tungsten cathode and its immediate vicinity during proposed reduction of $\mathrm{Nd}(\mathrm{III})$ ions from the used oxide-fluoride electrolyte. However, the deposition which minimizes accumulation of $\mathrm{Nd}$ metal droplets in the electrolyte on account of favouring increased quantities of $\mathrm{Nd}$ metal remaining on the cathode surface should reduce the unwanted effects of the disproportionation reaction. Potentiostatic Nd deposition on inert electrodes, like $\mathrm{W}$ and Mo, performed with moderately high overpotentials, while not entering the Li electrodeposition potential range, might be an answer [13,20]. Additional benefit of low overvoltage electrodeposition is the electrolytic production of neodymium from oxide-fluoride media with potential for zero emission of fluorocarbon compounds [15,16,20,29].

Neodymium "long time" depositions (those lasting for more than $10 \mathrm{~min}$ ) were done potentiostatically under small neodymium deposition overpotentials.

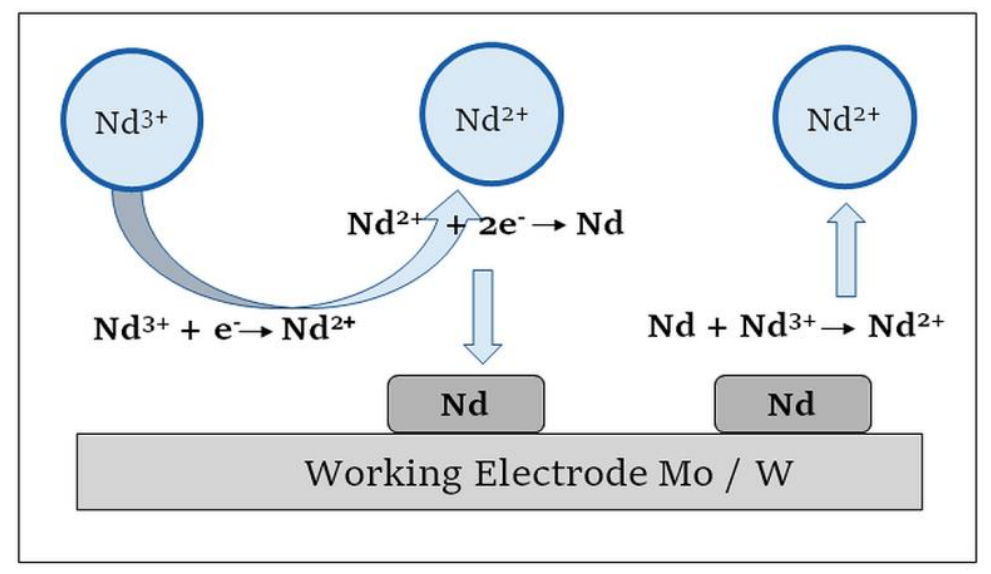

Figure 7. Schematic presentation of the proposed reduction reactions of $\mathrm{Nd}(\mathrm{III})$ ions and disproportionation reaction including $\mathrm{Nd}(0)$ and $\mathrm{Nd}(\mathrm{III})$. 
An example done on tungsten electrode is presented in Fig. 8a). The XRD analysis of the solidified electrolyte, from the close vicinity of the $\mathrm{W}$ electrode after $\mathrm{Nd}$ deposition at $-0.90 \mathrm{~V}$ for $1 \mathrm{~h}$ from molten $\mathrm{NdF}_{3}+\mathrm{LiF}+\mathrm{Nd}_{2} \mathrm{O}_{3}$, Fig. 8b), exhibits the diffraction peaks characteristic of hexagonal $\mathrm{NdF}_{3}$ [JCPDS No. 01-078-1859], face centred cubic LiF [01-072-1538] and the diffraction peaks characteristic of face centred cubic $\mathrm{NdF}_{2}$ [JCPDS No. 00-033-0934]. There was no metal neodymium recorded by XRD in the electrolyte analysed, which supports some findings from similar electrolytes [13,26]. It should be mentioned that the XRD spectra $\mathrm{NdF}_{2}$ [JCPDS No. 00-033-0934] and NdOF [JCPDS No. 00050-0635] appear at very close positions on the $2 \theta$ scale and therefore it was very difficult to assign recorded peaks to either of them. We opted for $\mathrm{NdF}_{2}$.
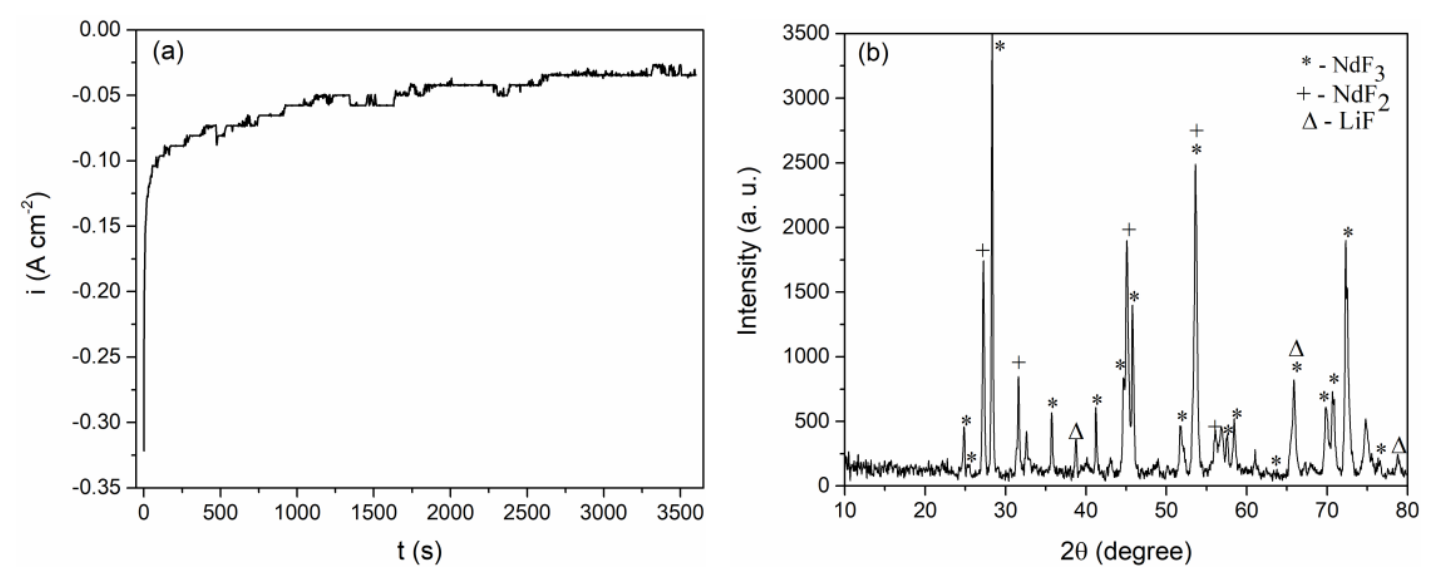

Figure 8. a) Chronoamperogram of the electrodeposition of neodymium onto $\mathrm{W}$ at $-0.90 \mathrm{~V}$ vs. $\mathrm{W}$ for one hour from molten oxide-fluoride electrolyte, at $1050{ }^{\circ} \mathrm{C}$; b) XRD spectra of the solidified electrolyte taken from the vicinity of the $\mathrm{W}$ working electrode after deposition presented in a).

Photographs of the working electrodes (W and Mo) covered with a thin layer of the solidified electrolyte used after potentiostatic neodymium deposition are presented in Figs. 9 and 10. Corresponding XRD analyses of the samples from Fig. 9a) and Fig. 10a) are displayed in Figs. 9b) and 10b). The XRD spectra of the deposit obtained on W electrode after deposition at - $0.85 \mathrm{~V}$ vs. W for 30 min from the oxide-fluoride electrolyte used, at $1050{ }^{\circ} \mathrm{C}$, is seen in Fig. 9b). Besides the presence of $\mathrm{NdF}_{3}$ and $\mathrm{NdF}_{2}$ (and possibly $\mathrm{NdOF}$ ), the spectra revealed the presence of metal $\mathrm{Nd}$ obtained during deposition [JCPDF No. 03-065-3424]. Similar results were obtained on Mo electrode after deposition at - $0.90 \mathrm{~V}$ vs. $\mathrm{W}$ for $1 \mathrm{~h}$ from the same electrolyte, at $1050{ }^{\circ} \mathrm{C}$, Fig. 10b). XRD spectrum showed the presence of $\mathrm{NdF}_{3}, \mathrm{NdF}_{2}$ and $\mathrm{Nd}$ metal in the deposit. Prolonged deposition on $\mathrm{W}$ working electrode at $0.80 \mathrm{~V}$ after $4 \mathrm{~h}$, in molten $\mathrm{NdF}_{3}+\mathrm{LiF}+\mathrm{Nd}_{2} \mathrm{O}_{3}$ electrolyte system, at $1050{ }^{\circ} \mathrm{C}$, provoked more metallic $\mathrm{Nd}$ on the working substrate, Fig. 11. 

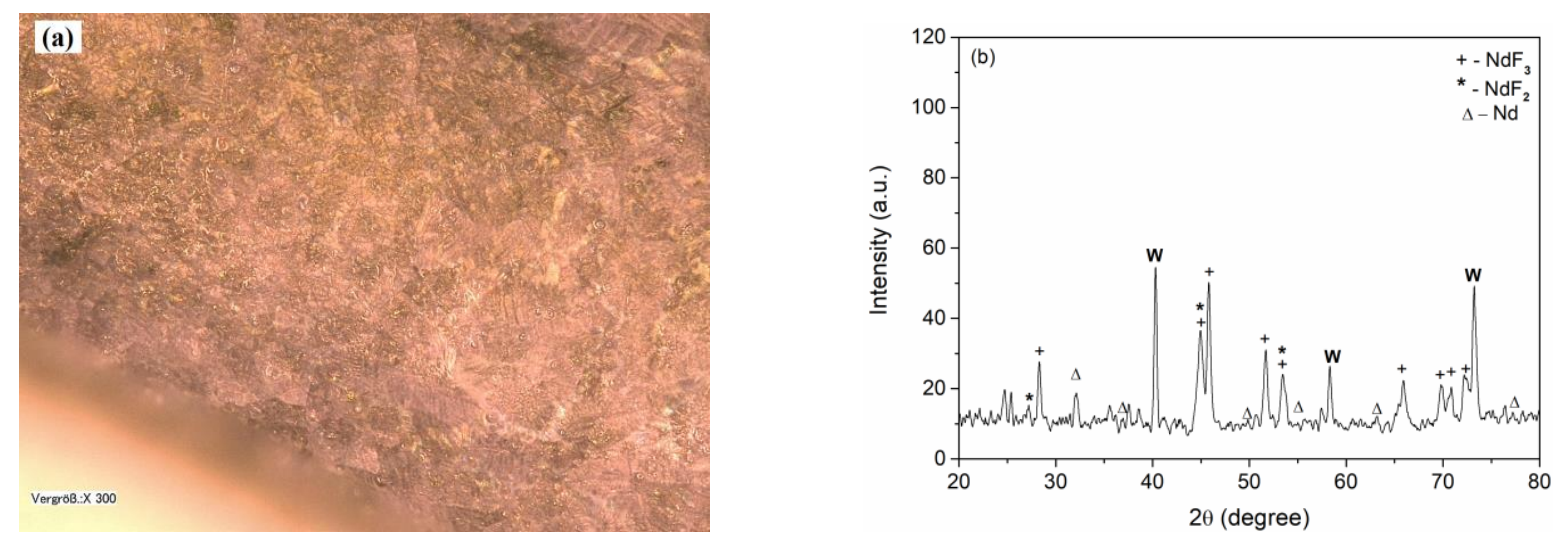

Figure 9. a) Optical image of $\mathrm{W}$ electrode and adhering electrolyte obtained after deposition at $-0.85 \mathrm{~V}$ vs. W for $30 \mathrm{~min}$ from molten oxide-fluoride electrolyte, at $1050{ }^{\circ} \mathrm{C}$; b) XRD spectra of the sample shown in a).
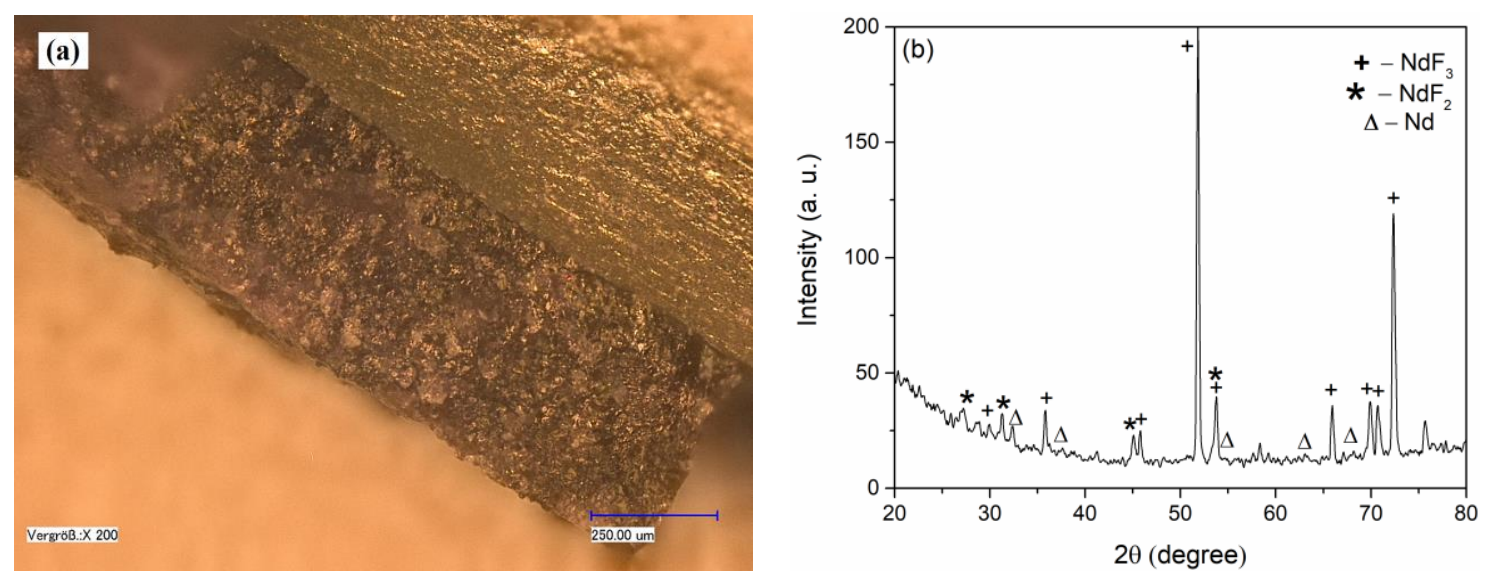

Figure 10. a) Optical image of Mo electrode and adhering electrolyte after deposition at - $0.90 \mathrm{~V}$ for $1 \mathrm{~h}$ from molten oxide-fluoride electrolyte, at $1050^{\circ} \mathrm{C}$; b) XRD of the sample given in a).

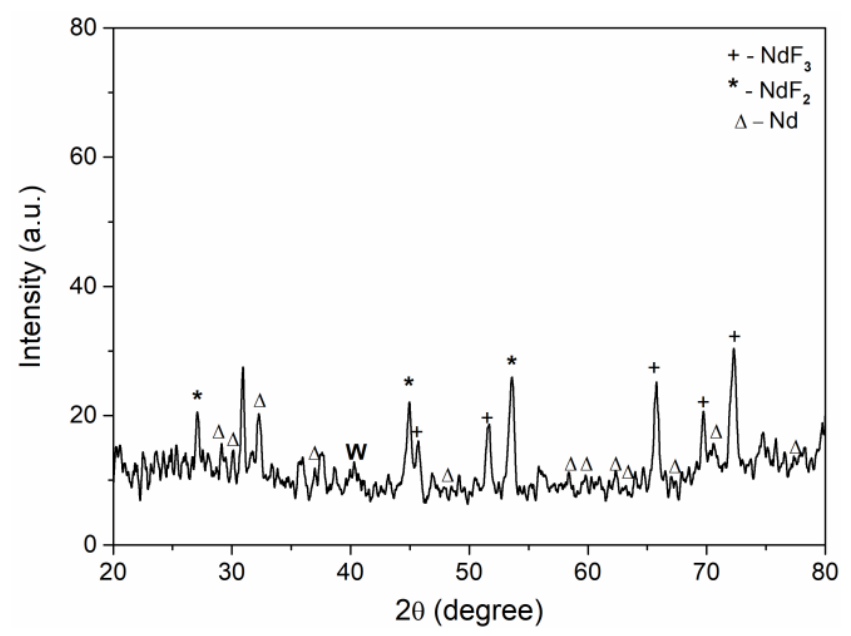

Figure 11. XRD spectra of $\mathrm{W}$ electrode and adhering electrolyte obtained after deposition at $-0.80 \mathrm{~V}$ for four hours from molten oxide-fluoride electrolyte, at $1050{ }^{\circ} \mathrm{C}$. 
XRD analysis recorded presence of metal neodymium on both $\mathrm{W}$ and Mo working electrode substrates after neodymium potentiostatic deposition performed for some time at the potentials negative to $-0.75 \mathrm{~V}$ vs. W. However, since the analysis was done on the samples with the thin film of the electrolyte being present on the electrode, it has to be assumed that the recorded metal neodymium is at least in part shared between the electrolyte layer and the electrode surface. The longer the deposition, the higher was the intensity of neodymium peaks compared to other recorded phases in the XRD diagrams of the thin electrolyte layer and the electrode used. Figure 11 is an example and presents a XRD analysis of the tungsten electrode covered with a thin layer of the electrolyte. It should be noted that only a small number of papers $[14,19,30,31]$ report Nd metal detected by XRD on the working electrodes used and even smaller number of them claim that their XRD examination of the electrolyte found no Nd metal [13,26].

The explanation for almost identical behaviour for tungsten and molybdenum as working electrodes in the used electrolytes should be found in their identical body centred cubic crystal structure [32], similar lattice parameters (W $3.1652 \AA$ [33], Mo $3.1470 \AA$ [34]), comparable Pauling electronegativities (2.36 eV for W, $2.16 \mathrm{eV}$ for Mo) and very close reversible potentials measured in the electrolyte used $\left(0.00 \mathrm{~V}\right.$ vs. $\mathrm{W}$ for $\mathrm{W}$ and $0.01 \mathrm{~V}$ vs. $\mathrm{W}$ for Mo). At the temperature of $1060{ }^{\circ} \mathrm{C}$ molybdenum lattice parameter becomes even closer to the tungsten's $3.1677 \AA$ [34].

\section{CONCLUSIONS}

As working electrodes in neodymium electrodeposition from oxide-fluoride melt tungsten and molybdenum behave almost identically. The explanation should be found in their identical body centred cubic crystal structure, very similar crystal lattice parameters, comparable Pauling electronegativities and very close reversible potentials measured in the electrolytes used.

On both cathode substrates used, $\mathrm{W}$ and Mo, electrochemical reduction of neodymium complexed ions from $\mathrm{LiF}+\mathrm{NdF}_{3}$ and $\mathrm{LiF}+\mathrm{NdF}_{3}+\mathrm{Nd}_{2} \mathrm{O}_{3}$ electrolytes proceeded in two steps: $\mathrm{Nd}(\mathrm{III})+\mathrm{e}^{-}$ $\rightarrow \mathrm{Nd}(\mathrm{II})$ and $\mathrm{Nd}(\mathrm{II})+2 \mathrm{e}^{-} \rightarrow \mathrm{Nd}(0)$ which are predominantly mass transfer controlled. Starting reduction potentials for both steps on both electrode surfaces were very similar in value (first around $-0.30 \mathrm{~V}$ vs. $\mathrm{W}$ and second at around $-0.60 \mathrm{~V}$ vs. W). Both steps: $\mathrm{Nd}(\mathrm{III}) \leftrightarrow \mathrm{Nd}(\mathrm{II})$ and $\mathrm{Nd}(\mathrm{II}) \leftrightarrow \mathrm{Nd}(0)$ were found to be reversible reactions limited by mass transfer.

Low overvoltage electrodeposition onto both used substrates, $\mathrm{W}$ and Mo, did not leave neodymium metal droplets in the solidified electrolyte taken from the close vicinity to the electrodes. It appears that after the deposition, the deposited metal resides predominantly at the working electrode surface.

Although it may be considered an inefficient method by industrial standards based on its yield, low voltage (low overpotential neodymium electrodeposition) electrolysis of oxide-fluoride melts appears to produce very low level of carbon oxides, fluorine and fluorocarbon gases from the anode. This might recommend Nd low overpotential controlled electrodeposition from fluoride melts onto Mo and $\mathrm{W}$ as an ecologically more acceptable procedure. 


\section{ACKNOWLEDGEMENT}

Part of the research was supported by the funds of the bilateral research project (ID: 451-03-01971/201809/4) supported by the Ministry of Education, Science and Technological Development of the Republic of Serbia and German Academic Exchange Service (DAAD). V.S.C., N.M.V., and J.S.S., acknowledge the financial support received from the Ministry of Education, Science and Technological Development of the Republic of Serbia (Grant No. 451-03-68/2020-14/200026).

\section{References}

1. A. Abbasalizadeh, S. Seetharaman, P. Venkatesan, J. Sietsma, Y. Yang, Electrochim. Acta, 310 (2019) 146-152.

2. Y. Yang, C. Lan, L. Guo, Z. An, Z. Zhao, B. Li, Sep. Purif. Technol., 233 (2020) 116030.

3. Z. Hua, H. Liu, J. Wang, J. He, S. Xiao, Y. Xiao, Y. Yang, ACS Sustain. Chem. Eng., 5 (2017) 8089-8096.

4. $\quad$ D. Shen, R. Akolkar, J. Electrochem. Soc., 164 (2017) H5292-H5298.

5. $\quad$ M. Razo-Negrete, Int. J. Electrochem. Sci., 14 (2019) 10431-10447.

6. M. Firdaus, M.A. Rhamdhani, Y. Durandet, W.J. Rankin, K. McGregor, J. Sustain. Metall., 2 (2016) 276-295.

7. M. Ciumag, M. Gibilaro, L. Massot, R. Laucournet, P. Chamelot, J. Fluor. Chem., 184 (2016) $1-7$.

8. C. Hamel, P. Chamelot, P. Taxil, Electrochim. Acta, 49 (2004) 4467-4476.

9. C. Shiguan, Y. Xiaoyong, Y. Zhongxing, L. Qingtao, Rare Met., 13 (1994) 46-49.

10. R. Thudum, A. Srivastava, S. Nandi, A. Nagaraj, R. Shekhar, Trans. Institutions Min. Metall. Sect. C Miner. Process. Extr. Metall., 119 (2010) 88-92.

11. A. Novoselova, V. Smolenski, Electrochim. Acta, 87 (2013) 657-662.

12. H. Tang, B. Pesic, J. Nucl. Mater., 458 (2015) 37-44.

13. C. Huang, X. Liu, Y. Gao, S. Liu, B. Li, Faraday Discuss., 190 (2016) 339-349.

14. X. Liu, C. Huang, B. Li, Mater. Trans., 58 (2017) 395-399.

15. E. Stefanidaki, C. Hasiotis, C. Kontoyannis, Electrochim. Acta, 46 (2001) 2665-2670.

16. K. Milicevic, D. Feldhaus, B. Friedrich, O. Martin (Ed.), Miner. Met. Mater. Ser., (2018), pp. 1435-1441.

17. E. Bourbos, A. Karantonis, L. Sygellou, I. Paspaliaris, D. Panias, Metals (Basel)., 8 (2018) 803.

18. E. Bourbos, I. Giannopoulou, A. Karantonis, D. Panias, I. Paspaliaris, Rare Earths Ind. Technol. Econ. Environ. Implic., (2015), pp. 156-162.

19. A. Abbasalizadeh, L. Teng, S. Sridhar, S. Seetharaman, Trans. Institutions Min. Metall. Sect. C Miner. Process. Extr. Metall., 124 (2015) 191-198.

20. V.S. Cvetković, D. Feldhaus, N.M. Vukićević, T.S. Barudžija, B. Friedrich, J.N. Jovićević, Metals (Basel)., 10 (2020) 576.

21. X. Hu, Z. Wang, B. Gao, Z. Shi, F. Liu, X. Cao, J. Rare Earths, 28 (2010) 587-590.

22. X. Guo, Z. Sun, J. Sietsma, B. Blanpain, M. Guo, Y. Yang, Ind. Eng. Chem. Res., 57 (2018) 1380-1388.

23. A. Kaneko, Y. Yamamoto, C. Okada, J. Alloys Compd., 193 (1993) 44-46.

24. H. Tamamura, T. Shimo-oka, M. Utsunomiya, ECS Proc. Vol., 1990-17 (1990) 611-625.

25. M. Gibilaro, L. Massot, P. Chamelot, P. Taxil, J. Nucl. Mater., 382 (2008) 39-45.

26. Z. Chen, C. She, H. Zheng, W. Huang, T. Zhu, F. Jiang, Y. Gong, Q. Li, Electrochim. Acta, 261 (2018) 289-295.

27. G.G. Lee, S.K. Jo, C.K. Lee, H.Y. Ryu, J.H. Lee, TMS Annu. Meet., 15-19-Marc (2015) 249252.

28. R. Greef, R. Peat, L.M. Peter, D. Pletcher, J. Robinson, Instrumental Methods in Electrochemistry, First Edit, Ellis horwood limited, (1985) Chichester. 
29. R. Keller, K. Larimer, R. Bautista, M.M. Wong (Eds.), Rare Earths-Science, Technol. Appl. III, The Minera, (1997) Warrendale, pp. 175-180.

30. A. Uehara, K. Fukasawa, T. Nagai, T. Fujii, H. Yamana, J. Nucl. Mater., 414 (2011) 336-339.

31. J. Öhl, J. Appl. Electrochem., 48 (2018) 765-772.

32. I.K. Suh, H. Ohta, Y. Waseda, J. Mater. Sci., 23 (1988) 757-760.

33. Y. Waseda, K. Hirata, M. Ohtani, High Temp High Press., 7 (1975) 221-226.

34. $\quad$ R.G. Ross, W. Hume-Rothery, J. Less Common Met., 5 (1963) 258-270.

(C) 2020 The Authors. Published by ESG (www.electrochemsci.org). This article is an open access article distributed under the terms and conditions of the Creative Commons Attribution license (http://creativecommons.org/licenses/by/4.0/). 